\title{
Fluoride releasing restorative materials: a review
}

\author{
Brunda Neti1,*, Gowthami Sayana1, Lahari Muddala1, Satyanarayana Raju Mantena², Anusha Yarram³, \\ Harsha GVD4 \\ ${ }^{1}$ Undergraduate Student, Vishnu Dental College, Bhimavaram-534202, West Godavari, Andhra Pradesh, \\ India. \\ ${ }^{2}$ Professor, ${ }^{3}$ Reader, Department of Prosthodontics and Implantology, Vishnu Dental College, Bhimavaram \\ -534202, West Godavari, Andhra Pradesh, India. \\ 4Senior Lecturer, Department of Orthodontics, Vishnu Dental College, Bhimavaram-534202, \\ West Godavari, Andhra Pradesh, India.
}

\section{N F O R M A T I O}

\section{Article History}

Received 9th February 2020

Accepted $17^{\text {th }}$ February 2020

Available online

$9^{\text {th }}$ March 2020

\section{K E Y W O R D S}

Anticariogenic property

Fluoride release

Glass ionomer cement

Composites

Amalgam

\section{A B S T R A C T}

Fluoride compounds are incorporated as anticariogenic agents in numerous restorative materials. Incorporation of fluoride into restorative materials impart anticariogenic character by various mechanisms including reduction of demineralisation, enhancement of remineralisation, interference of pellicle and plaque and inhibition of microbial growth and metabolism. In addition, the application of the topical fluoride in the form of toothpaste and varnish is also considered as the most effective method of caries prevention. The fluoride combines with HA of the tooth and forms an acid-resistant fluorapatite (FAP) crystals. Also, fluoride enters into the cells of the bacteria and inhibits carbohydrate metabolism, which eventually kills the bacteria. The objective of this review was to emphasise the fluoride-releasing restorative materials available in dentistry.

\section{Introduction}

Dental caries is one of the most common and prevalent diseases occurring in humans across the globe [1-6]. Dental caries is an infectious disease of the dentition characterized by localized destruction of the tooth. Numerous microorganisms reside in the saliva and on the natural tooth may produce various acids that result in demineralisation of the tooth tissues. This demineralisation may be initiated in the form of a small lesion and will be progressed towards the inner tooth tissues. Pulpal necrosis might take place if this caries reaches to the pulpal tissue. The infection may be advanced into the underlying periodontal tissue through the root apex, causing periapical abscesses. The major factors, which influence dental caries, though it is a multifactorial disease, are the host such as the teeth and saliva; the microorganisms which produce acids on the tooth surface; and consumption of the fermentable carbohydrate diet [7].

The tooth is a composite structure that is composed of the phosphate-based mineral HA in the enamel, collagen in the dentine, and living tissues [8-10]. The enamel of the tooth may develop high resistance to localized demineralisation on its exposure to food, various drinks, and the microorganisms of the mouth [11-14]. However, demineralization of the natural tooth may be initiated when the $\mathrm{pH}$ of the oral cavity is decreased. This decrease in $\mathrm{pH}$ encourages the chemical

Correspondence: ${ }^{*}$ Corresponding author Email Address: $\underline{\text { brundaneti@gmail.com }}$

How to cite this article: Neti B, Sayana G, Muddala L, Mantena SR, Yarram A, Harsha GVD. Fluoride releasing restorative materials: a review. Int J Dent Mater 2020;2(1): 19-23. 
dissolution of both the organic and inorganic matrix components of the tooth. During this, $\mathrm{Ca}+2$ and $\mathrm{PO} 4+3$ move away from the enamel surface and initiates demineralization [15]. The water content of enamel and dentine would facilitate acid diffusion in and mineral content out of tooth [16].

On the other hand, increase in the $\mathrm{pH}$ of the oral cavity towards neutrality, availability of fluoride ions (very minimal quantity), maintaining of proper oral hygiene and additional supplements of fluoride ions may help in remineralising the tissue surfaces.

Saliva, especially, is a significant source for calcium and phosphate that helps in maintaining supersaturation with respect to tooth minerals, therefore inhibiting tooth demineralization during periods of low $\mathrm{pH}$, and they promote tooth remineralization when the $\mathrm{pH}$ returns to a neutral state. Furthermore, saliva also possesses cleansing effect and imparts antibacterial action [17].

Fluoride is well documented as an anticariogenic agent. A variety of mechanisms are involved in the anticariogenic effect of fluoride, including reduction of demineralisation, enhancement of remineralisation, interference of pellicle and plaque and inhibition of microbial growth and metabolism. Application of the topical fluoride in the form of toothpaste and varnish is considered as the most effective method of caries prevention. The fluoride combines with HA of the tooth and forms an acid-resistant fluorapatite (FAP) crystals. In addition, fluoride also enters into the cells of the bacteria and inhibits carbohydrate metabolism, which eventually kills the bacteria. The former mechanism of anticariogenic property is called as a Physicochemical method, and the latter is termed as a biological method in arresting caries [18]. Numerous researchers investigated the effect of incorporation of fluorides into various restorative materials on their anticariogenic property and remineralisation of the natural tooth. Currently, various restorative materials including traditional glass ionomer cements (GICs), high viscosity GICs, cermet cements, resin-modified glass ionomer cements (RMGICs), nano-ionomer cements, compomers, glass carbomers, giomers; and composite resins contain fluorides and they exhibit anticariogenic property. These restorative materials release an adequate amount of fluoride into the oral environment and increase the level of fluoride in saliva, plaque and hard dental tissues $[18,19]$. This review emphasises on the contemporary fluoride-releasing restorative materials used in dentistry.

\section{Fluoride Releasing restorative materials}

\subsection{Glass Ionomer cements}

Glass ionomer cements (GICs) were developed to utilise the advantages of both silicate and polycarboxylate cements by Wilson and Kent in 1969. Glass ionomer materials available in the form of alumino-fluorosilicate glass powder and an aqueous solution of polyacrylic acid [20]. Traditional GICs undergo an acid-base reaction on mixing the glass powder with the liquid. Glass releases various ionic constituents during the setting reaction, including fluoride. Two processes have been proposed to describe the mechanism of fluoride release from glass-ionomers into an aqueous environment. The first process is a short-term reaction in which the outer surfaces of alumino-fluoro-silicate glass particles rapidly dissolves into solution. In contrast, in the second process, there is more gradual dissolution and resulted in the sustained diffusion of ions through the bulk cement [21-23].

During the setting reaction, an initial burst of fluoride release may be observed from the glass particles, and this release is very high over the first 24 hours. It was reported that the contemporary GICs release maximum fluoride during the first 24-48h [24-27]. Numerous studies estimated that the amount of fluoride released was in the range of 5 to 155ppm [25-28]. Bell et al. [28] evaluated the released fluoride from GICs into artificial saliva at different time intervals. They reported that the GICs released 1.0 ppm of fluoride within 10 min after immersion and the cumulative total fluoride release was 15 ppm in the first 24 hours. However, the initial burst of fluoride release may slow down over a period, and a sustained release of fluoride in lower concentrations might occur in GICs. Several in vitro studies reported the long-term fluoride release from glass-ionomers from a period of few months to a maximum period of three years [29-31].

\subsection{Modified glass ionomer cements}

Metal-reinforced glass-ionomers release less fluoride content compared to conventional glass-ionomer cements [29, 32-34]. This less release in fluoride content can be attributed to the availability of less fluoride as it may be replaced by the silver or due to the formation of silver fluoride which binds the fluoride ions into the cement that prevents the release of the fluoride [35]. 
Resin-modified glass-ionomer cements (RMGICs) were developed to address the problems of moisture sensitivity and low initial mechanical strengths typical for conventional glass-ionomers [18]. Both conventional and RMGICs were found to have a similar pattern of fluoride release from them. Several studies showed the maximum amount of fluoride release (5$35 \mu \mathrm{g} / \mathrm{cm} 2$ ) from different RMGICs during the first 24hours in various storage media [27, 36-37]. From the literature available, it can be observed that the mean concentration of fluoride release from RMGIC specimens into deionized water over the first 24 hours after setting amounted from $22-65 \mathrm{ppm}$ for the first $6 \mathrm{~h}$ to $3-20 \mathrm{ppm}$ for the $18-24 \mathrm{~h}$ period [24]. Therefore, similar to conventional GICs, it is evident that the amount of fluoride release would be decreased as the restoration is ageing.

On the other hand, polyacid modified composite (Compomer) does not show initial fluoride release burst effect $[26,27,39]$ as shown by conventional and RMGICs. However, the levels of fluoride release remain relatively constant over time [26]. This can be attributed to a more tightly bound and/or less hydrophilic matrix of the composite resin [40], and fluoride is tightly bound to the filler particles, which are enclosed in the polymer matrix [37]. Polyacid-modified composites containing glass fillers and ytterbium trifluoride are reported to release significant amounts of fluoride than those containing Strontium fluoride [25,41-44].

Giomers are the new group of materials developed in glass ionomer cements family. As compomers, giomers also do not show an initial 'burst' effect of fluoride release. The amounts of fluoride release from the giomers are considered less than the conventional glass ionomers, but, significantly more than the compomers and composite [26, 45].

\subsection{Composites}

Resin-based composites are widely used in dentistry for various applications. Composites are composed of the resin matrix, filler particles and coupling agents [18, 46-48]. Earlier composites do not possess anticariogenic effect as they do not contain fluorides. However, recently developed composite formulations contain fluorides either in the form of inorganic salts or leachable glasses or organic fluoride. The amount and rate of fluoride release from these composites depend on the type of fluoride, amount of fluoride, the size of fluoridated filler particles and the hydrophilicity of the polymer matrix [48-51]. It was reported in the literature that the fluoride release from composites is lower compared to fluoride released from conventional GIC, RMGIC and compomers [25,31,37,40,52].

\subsection{Amalgam}

Amalgam is a direct metallic restoration, and it is an alloy of mercury with silver, tin, and copper [18]. Numerous studies investigated the amount of fluoride released from amalgam [53-55]. Several in vitro studies showed that the amalgam restorations release very fewer fluoride levels compared to conventional and modified GICs [53, 54]. Garcia-Godoy F et al. reported very less amount of fluoride release from amalgam restoration (less than $0.02 \mathrm{ppm}$ ) within four weeks [55].

\section{Conclusion}

Fluoride released from restorative materials effectively prevent the formation of secondary caries. Fluoride levels from various restorative materials may vary depending on the type and amount of fluoride incorporated into the restorative materials formulations. However, fluoride release from different fluoridated restorative materials may decrease on the ageing of restoration.

Conflicts of interest: Authors declared no conflicts of interest.

\section{Financial support: None}

\section{References}

1. Brown LJ, Winn DM, White BA, Dental caries, restorations and tooth conditions in U.S. adults, 19881991. J Am Dent Assoc. 1996; 127:1315-25.

2. Featherstone JDB, Prevention and reversal of dental caries: role of low level fluoride. Community Dent Oral Epidemiol. 1999; 27:31-40.

3. Kidd EAM, Caries management. Dent Clin North Am. 1999;43:743-63.

4. Evans CA, Kleinman DV, The surgeon general's report on America's oral health: opportunities for the dental profession. J Am Dent Assoc. 2000; 131: 1721-8.

5. Featherstone JDB, The science and practice of caries prevention. J Am Dent Assoc. 2000;131:887-99. 
6. Warren JJ, Cowen $\mathrm{HJ}$ et al, Dental caries prevalence and dental care utilization among the very old. J Am Dent Assoc. 2000 131:1571-9.

7. Lamont RJ, Egland PG. Dental Caries (in) Molecular Medical Microbiology. Academic Press, 2nd Edition, 2015:945-955.

8. Ji W, Yang F, Ma J, et al. Biomaterials Incorporation of stromal cell-derived factor-1a in PCL/ gelatin electrospun membranes for guided bone regeneration. Biomaterials. 2013;34(3):735-745.

9. Shepherd TJ, Dirks W, Manmee C, et al. Reconstructing the life-time lead exposure in children using dentine in deciduous teeth. Sci Total Environ. 2012;425:214-222.

10. Vanderby R, Provenzano PP. Collagen in connective tissue: from tendon to bone. J Biomech. 2003;36(10):1523-1527.

11. Ren YF. Dental erosion: etiology, diagnosis and prevention. Dental Hygenist. 2011:75-84.

12. Scaramucci T, Carvalho JC, Hara AT, Zero DT. Causes of Dental Erosion: Extrinsic Factors. Berlin: Springer International Publishing; 2015:6996.

13. Barbour ME, Finke M, Parker DM, Hughes JA, Allen GC, Addy M. The relationship between enamel softening and erosion caused by soft drinks at a range of temperatures. J Dent. 2006;34(3):207213.

14. Meredith N, Sherriff M, Setchell DJ, Swanson SA. Measurement of the microhardness and young's modulus of human enamel and dentine using an indentation technique. Arch Oral Biol. 1996;41 (6):539-545.

15. Belen Şirinoğlu Çapan, Serap Akyüz. Current Fluoride-releasing Restorative Materials Used in Pediatric Dentistry. Clin Exp Health Sci 2016; 6(3): 129-134.

16. Featherstone JD, Lussi A. Understanding the chemistry of dental erosion. Monogr Oral Sci. 2006;20:66-76.

17. Dowd F. Saliva and dental caries. Dent Clin North Am. 1999;43(4): 579-597.

18. Alla RK. Dental Materials Science. 1st Edition, Jaypee Brothers Medical Publishers Pvt. Ltd. New Delhi, India 2013; 91-129.

19. Anusavice KJ. Philips'Science ofDental Materials.11th Edition, Elsevier, India, 2010; 471-486.

20. Ramaraju DVS, Alla RK, Ramaraju AV, Raju MAKV. A Review of Conventional and Contemporary Luting Agents Used in Dentistry.AmJ MaterSci Eng. 2014;2(3): 28-35.
21. Lee SY, Dong DR, Huang HM, Shih YH. Fluoride ion diffusion from a glass-ionomer cement. J Oral Rehabil 2000;27:576-86.

22. Williams JA, Billington RW, Pearson GJ. A long term study of fluoride release from metalcontaining conventional and resin-modified glassionomer cements. J Oral Rehabil 2001;28:41-7.

23. Dhondt CL, De Maeyer EA, Verbeeck RM. Fluoride release from glass ionomer activated with fluoride solutions. J Dent Res 2001;80:1402-6.

24. Creanor SL, Carruthers LM, Saunders WP, Strang R, Foye RH. Fluoride uptake and release characteristics of glass ionomer cements. Caries Res 1994;28:322-8.

25. Attar N, Onen A. Fluoride release and uptake characteristics of aesthetic restorative materials. J Oral Rehabil 2002;29:791-8.

26. Yap AU, Tham SY, Zhu LY, Lee HK. Short-term fluoride release from various aesthetic restorative materials. Oper Dent 2002;27:259-65.

27. Attar N, Turgut MD. Fluoride release and uptake capacities of fluoride-releasing restorative materials. Oper Dent 2003;28:395-402.

28. Bell A, Creanor SL, Foye RH, Saunders WP. The effect of saliva on fluoride release by a glassionomer filling material. J Oral Rehabil 1999;26:407-12.

29. Williams JA, Billington RW, Pearson GJ. A long term study of fluoride release from metalcontaining conventional and resin-modified glassionomer cements. J Oral Rehabil 2001;28:41-7.

30. Yli-Urpo H, Vallittu PK, Narhi TO, Forsback AP, Vakiparta M. Release of silica, calcium, phosphorus, and fluoride from glass ionomer cement containing bioactive glass. J Biomater Appl 2004;19:5-20.

31. Preston AJ, Mair LH, Agalamanyi EA, Higham SM. Fluoride release from aesthetic dental materials. J Oral Rehabil 1999;26:123-9.

32. DeSchepper EJ, Berr III EA, Cailleteau JG, Tate WH. A comparative study of fluoride release from glassionomercements. Quintessence Int 1991;22: 215-9.

33. De Moor RJ, Verbeeck RM, De Maeyer EA. Fluoride release profiles of restorative glass ionomer formulations. Dent Mater 1996;12:88-95.

34. Williams JA, Billington RW, Pearson G. Silver and fluoride ion release from metal-reinforced glassionomer filling materials. J Oral Rehabil 1997;24:369-75.

35. el Mallakh BF, Sarkar NK. Fluoride release from glass-ionomer cements in de-ionized water and artificial saliva. Dent Mater 1990;6:118-22. 
36. de Araujo FB, Garcia-Godoy F, Cury JA, Conceicao EN. Fluoride release from fluoride-containing materials. Oper Dent 1996;21:185-90.

37. Karantakis P, Helvatjoglou-Antoniades M, Theodoridou-Pahini S, Papadogiannis Y. Fluoride release from three glass ionomers, a compomer, and a composite resin in water, artificial saliva, and lactic acid. Oper Dent 2000;25:20-5.

38. Hayacibara MF, Ambrozano GM, Cury JA. Simultaneous release of fluoride and aluminum from dental materials in various immersion media. Oper Dent 2004;29: 16-22.

39. Yip HK, Smales RJ. Fluoride release from a polyacid-modified resin composite and 3 resinmodified glass-ionomer materials. Quintessence Int 2000;31: 261-6.

40. Vermeersch G, Leloup G, Vreven J. Fluoride release from glass-ionomer cements, compomers and resin composites. J Oral Rehabil 2001;28:26-32.

41. Muller U, Kielbassa AM, Schulte-Monting J, Hellwig E. Fluoride release from light-curing restorative materials. Am J Dent 2000;13:301-4.

42. Abu-Bakr NH, Han L, Okamoto A, Iwaku M. Effect of alcoholic and low-pH soft drinks on fluoride release from compomer. JEsthetDent 2000;12:97-104.

43. Vercruysse CW, De Maeyer EA, Verbeeck RM. Fluoride release of polyacid-modified composite resins with and without bonding agents. Dent Mater 2001;17: 354-8.

44. Sales D, Sae-Lee D, Matsuya S, Ana ID. Short-term fluoride and cations release from polyacid-modified composites in a distilled water, and an acidic lactate buffer. Biomaterials 2003;24:1687-96.

45. Itota T, Carrick TE, Yoshiyama M, McCabe JF. Fluoride release and recharge in giomer, compomer and resin composite. Dent Mater 2004;20:789-95.

46. Ravi RK, Alla RK, Mohammad S, Devarhubli A, Dental Composites - A Versatile Restorative Material: An Overview. Ind J Dent Sci. 2013; 5(5): 111-5.

47. Konakanchi A, Alla RK, Guduri V. Coupling agents: Benevolant bindersin composites. Trends Biomatr Artif Organs. 2017; 31(3): 102-7.

48. Lavnya D, Divya B, Mantena SR, Madhu Varma K, Bheemalingeswara Rao D, Chandrappa V. Recent Advances in Dental Composites: An Overview. Int J Dent Mater 2019;1(2): 48-54.

49. Xu X, Burgess JO. Compressive strength, fluoride release and recharge of fluoride-releasing materials. Biomaterials 2003;24:2451-61.
50. Xu HH, Eichmiller FC, Antonucci JM, Flaim GM. Single-crystalline ceramic whisker-reinforced carboxylic acid-resin composites with fluoride release. Oper Dent 2000;25:90-7.

51. Xu HH, Eichmiller FC, Antonucci JM, Schumacher GE, Ives LK. Dental resin composites containing ceramic whiskers and precured glass ionomer particles. Dent Mater 2000;16:356-63.

52. Preston AJ, Agalamanyi EA, Higham SM, Mair LH. The recharge of esthetic dental restorative materials with fluoride in vitro-two years' results. Dent Mater 2003;19:32-7.

53. Tveit AB, Gjerdet NR. Fluoride release from a fluoride-containing amalgam, a glass ionomer cement and a silicate cement in artificial saliva. J Oral Rehabil 1981;8:237-41.

54. Garcia-Godoy F, Olsen BT, Marshall TD, Barnwell GM. Fluoride release from amalgam restorations lined with a silver-reinforced glass ionomer. Am J Dent 1990;3: 94-6.

55. Garcia-Godoy F, Chan DC. Long-term fluoride release from glass ionomer-lined amalgam restorations. Am J Dent 1991;4:223-5. 